\title{
SEX-SPECIFIC EVALUATION OF MACRO- AND MICRONUTRIENT INTAKE IN ADO- LESCENTS FROM PORTO ALEGRE/RS, BRAZIL
}

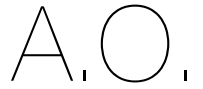

ARTIGO ORIGINAL

1 Centro Universitário Ritter dos Reis (Uniritter) Porto Alegre, RS, Brasil

2 Cesuca Centro

Universitário,

Cachoeirinha, RS, Brasil

3 Universidade Federal do Rio Grande do Sul, Hospital de Clínicas de Porto Alegre - FAMED, Porto Alegre, Brasil

${ }^{4}$ McGill University, Ludmer Centre for Neuroinformatic and Mental Health, Douglas Mental Health University Institute

Endereço para correspondência:

Tania Diniz Machado Universidade Federal do Rio Grande do Sul, Hospital de Clínicas de Porto Alegre FAMED, Porto Alegre, Bras aniadinizmachado@gmail.com

Histórico do artigo:

Recebido a 17 de dezembro de 2020

Aceite a 13 de junho de 202

\author{
AVALIAÇÃO SEXO-ESPECÍFICA DA INGESTÃO DE MACRO E \\ MICRONUTRIENTES EM ADOLESCENTES DE PORTO ALEGRE/ \\ RS, BRASIL
}

Letícia Figueiredo Pinheiro1: Juliana Paludo Valandro1; Roberta Dalle Molle²; Roberta Sena Reis ${ }^{3}$; Bárbara Cristina Ergang ${ }^{3}$ : Rudineia Toazza ${ }^{3}$ Amanda Brondani Mucellini ${ }^{3 *}$ Gisele Gus Manfro ${ }^{3}$ : Patrícia Pelufo Silveira'; Tania Diniz Machado ${ }^{3}$

\section{ABSTRACT}

INTRODUCTION: Adequate nutrient intake is important for individuals to reach their growth and development potential, especially during adolescence. While most previous studies have assessed the adequacy of food intake based on subject recall, a few have used a food frequency questionnaire validated for a specific population.

OBJECTIVES: To evaluate the adequacy of macro and micronutrient intake, according to the DRIs in adolescents using a validated food frequency questionnaire.

METHODOLOGY: This cross-sectional study was conducted as part of the Program of Anxiety Disorders in Childhood and Adolescence. In 2013/2014, an analysis of food consumption through the food frequency questionnaire, body composition and biochemical analysis were performed.

RESULTS: 38 adolescents (18 boys, 20 girls; mean [ \pm SD] age, $16.66 \pm 1.55$ years and $16.39 \pm 1.62$ years; mean body mass index, $21.23 \pm 3.7$ and $22.61 \pm 4.09 \mathrm{~kg} / \mathrm{m}^{2}$, respectively) were analyzed. A high prevalence of inadequate intake of folate (in $50 \%$ of boys and $65 \%$ of girls according to Estimated Average daily requirements (EAR), and sodium intake higher than the Tolerable Upper Intake Level (UL) in $88.89 \%$ of boys and $85 \%$ of girls were verified. Girls exhibited a high prevalence of inadequate calcium intake (55\%). Macronutrient intake, however, was within acceptable distribution ranges.

CoNCLUSIONS: Inadequate intake of folate and higher sodium intake were observed in both sexes, whereas inadequate calcium intake was observed only in girls. The occurrence of these inadequacies during adolescence can lead to lifelong health problems. It is especially concerning in girls because these inadequacies can cause serious consequences during pregnancy and, in turn, to the health of offspring.

\section{KEYWORDS}

Adolescent, Micronutrients, Nutrition requeriments, Nutrients

RESUMO

INTRODUÇÃO: A ingestão adequada de nutrientes é importante para que os indivíduos atinjam seu potencial de crescimento e desenvolvimento, principalmente durante a adolescência. Embora a maioria dos estudos anteriores tenha avaliado a adequação da ingestão de alimentos com base no recordatório $24 \mathrm{~h}$, poucos usaram um questionário de frequência alimentar validado para uma população específica.

OBJETIVos: Avaliar a adequação da ingestão de macro e micronutrients em adolescentes, de acordo com as DRIs usando um questionário de frequência alimentar validado.

METODOLOGIA: Este estudo transversal foi realizado como parte do Programa de Transtornos de Ansiedade na Infância e Adolescência. Em 2013/2014, foram realizadas análises de consumo alimentar por meio do questionário de frequência alimentar, composição corporal e análises bioquímicas.

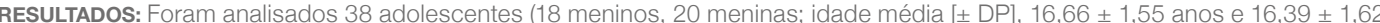
anos; índice de massa corporal médio, 21,23 $\pm 3,7$ e 22,61 $\pm 4,09 \mathrm{~kg} / \mathrm{m}^{2}$, respetivamente). Encontramos alta prevalência de ingestão inadequada de folato (em 50\% dos meninos e 65\% das meninas, de acordo com as necessidades diárias médias estimadas (EAR) e ingestão de sódio superior ao nível de ingestão superior tolerável (UL) em 88,89\% dos meninos e 85\%. As meninas apresentaram alta prevalência de ingestão inadequada de cálcio (55\%), mas a ingestão de macronutrientes estava dentro dos limites aceitáveis de ingestão

CONCLUSÕES: Ingestão inadequada de folato e maior ingestão de sódio foram observados em ambos os sexos, enquanto ingestão inadequada de cálcio foi observada apenas em meninas. A ocorrência dessas inadequações durante a adolescência pode levar a problemas de saúde ao longo da vida.Isso é especialmente preocupante nas meninas porque essas inadequações podem causar sérias conseqüências durante a gravidez e, por sua vez, para a saúde dos filhos.

PALAVRAS-CHAV

Adolescente, Micronutrientes, Necessidades nutricionais, Nutrientes 


\section{INTRODUCTION}

During adolescence, between 10 and 19 years of age, a healthy diet is important to promote growth and development. Adolescents are believed to be vulnerable to nutritional inadequacies due to their high energy and nutritional demands but generally poor dietary habits. Because of this vulnerability related to adolescent lifestyles, it is important to gain better understanding of their food consumption to develop strategies for promoting healthier lifestyles $(1,2)$.

The Food Frequency Questionnaire (FFQ) is one of the instruments available to evaluate habitual food consumption (3). This instrument comprises a list of foods and the frequency at which each food is consumed in a fixed period of time (e.g., previous 12 months), and provides qualitative or quantitative results regarding nutrient and food consumption. In Brazil, the Dietary Reference Intakes (DRIs) reference values for nutrient intake based on healthy individuals are used to evaluate the adequacy of nutrients ingested (4).

With regard to the general population, approximately 2 billion individuals worldwide ingest inadequate levels of micronutrients, which is associated with a high risk for the development of chronic, non-communicable diseases (5). A study conducted in Brazil reported insufficient consumption of calcium and vitamin $\mathrm{E}$, and excessive consumption of sodium, especially among boys. In addition, the inadequacy of vitamin $\mathrm{C}$ was higher in boys than in girls. In contrast, iron and phosphorus intake was higher in girls than in boys (6).

The objective of the present study was to evaluate, in a sex-specific manner, the consumption of macro- and micronutrient by adolescents in Porto Alegre, RS, Brazil. Few studies have performed a sexspecific food intake evaluation in adolescents. In addition, we used an instrument that is underexplored in evaluating food consumption inadequacy in this population — a semiquantitative FFQ — validated for adolescents from south Brazil.

\section{METHODOLOGY}

This cross-sectional study was nested in a cohort from the Programa de Transtornos de Ansiedade na Infância e Adolescência (PROTAIA), Porto Alegre, RS. The PROTAIA participants were selected from among six schools belonging to the Santa Cecilia Health area in Porto Alegre. Anthropometric and food consumption evaluations were performed in a representative sample of the cohort in 2013 and 2014.

\section{Food Consumption}

Adolescent food consumption was evaluated using the FFQ-Porto Alegre. It was developed and validated for adolescents, adults, and the elderly from south Brazil. It contains 135 food items and aims to retrospectively (previous year) record the consumption frequency, quantities, and portion sizes of specific foods (7).

Nutrient intake analyses were performed by converting food portion sizes into gram weights according to the information provided by the authors of the FFQ-Porto Alegre. If the participant reported different portion sizes, the number of grams consumed were determined using the Tabela de Avaliação do Consumo Alimentar em Medidas Caseiras (8). The information reported by participants regarding frequencies and quantities of food consumption were converted into daily equivalents. The nutritional composition of the foods was obtained from the food composition databases of the United States Department of Agriculture. If the food item was not available in these databases, nutritional information was collected from Brazilian food composition tables (8). If necessary, recipes were elaborated to determine their ingredients. The data were entered into in a spreadsheet (Excel 2013, Microsoft Corporation, Redmond, WA, USA) and, for each food item, the nutrient values and the total energy value (kcal) were calculated. Estimated daily intake of macro- and micronutrients was calculated using a syntax constructed using the Statistical Package for Social Sciences (SPSS) version 19.0 (IBM Corporation, Armonk, NY, USA). The adequacy of energy consumption and macro- and micronutrient (sodium, calcium, zinc, vitamin A, C, D, and E, folate, magnesium, potassium, and iron) intake were analyzed according to the recommendations from the DRls (9-11). The evaluation of macronutrient intake was assessed based on the acceptable macronutrient distribution ranges, and micronutrient intake inadequacy was based on the Estimated Average Requirement (EAR), which is the mean intake level to supply at least $50 \%$ of requirements in an individual's in a specific period of life, and on the Tolerable Upper Intake Level (UL), which is the maximum level of specific nutrients that an individual can ingest continuously and for a prolonged period without any risk of adverse effects.

\section{Anthropometric Evaluation}

Anthropometric evaluation was performed at the Research Center of the Hospital de Clínicas de Porto Alegre (HCPA). Height and weight were measured using precise and calibrated equipment (digital scale, Oswaldo Filizola, São Paulo, Brazil; and vertical Harpenden stadiometer). Each measurement was performed twice, and the mean was used for analysis. Body mass index (BMI) was calculated to evaluate the nutritional status based on the growth curves proposed by the World Health Organization (WHO) (12). Body fat percentage was evaluated using the bioelectrical impedance analysis method (Model 310.8, Biodynamics).

\section{Biochemical Tests}

For biochemical analysis, blood samples were collected in the morning after a fast of $12 \mathrm{~h}$ and centrifuged at $4000 \mathrm{rpm}$ for $10 \mathrm{~min}$. Glucose, total and high-density lipoprotein (HDL) cholesterol, and triglyceride levels were determined using an enzymatic colorimetric method, and insulin levels were determined using a commercially available chemiluminescence assay kit (ADVIA 1800 and ADVIA Centaur insulin assay, Siemens Healthcare Diagnostics Inc., Tarrytown, NY, USA). Low-density lipoprotein (LDL) was estimated using the Friedewald formula. Homeostasis Assessment Model-Insulin Resistance (HOMA$\mathrm{IR}$ ) index was calculated using the following equation: fasting serum insulin $(\mathrm{mU} / \mathrm{mL}) \times$ fasting serum glucose $(\mathrm{mmol} / \mathrm{L}) / 22.5$.

\section{Statistical Analyses}

Data were entered and analyzed using SPSS version 19.0. Qualitative variables are expressed as absolute and relative frequencies (\%), while quantitative variables are expressed as mean, standard error, standard deviation, or median and interquartile range, depending on data distribution verified using the Shapiro-Wilk normality test. Data comparison between the sexes was analyzed using the Student's t-test or Mann-Whitney test. Regardless of the distribution, analysis of covariance (ANCOVA) was performed adjusted by BMI to minimize possible confusion biases. Differences with $p<0.05$ were considered to be statistically significant.

\section{Ethics Approval}

The research project was registered in the Plataforma Brasil and approved by the Research Ethics Committee of the HCPA (CAAE number 5278112500005327). The research project adhered to regulations for studies involving human subjects, in particular, Resolution 466/2012 and 510/2016. The participants and their parents or guardians were informed and clarified about the research 
objectives and agreed to participate in the study by signing an informed consent form. Confidentiality with regard participant identity was assured.

\section{RESULTS}

Thirty-eight participants (20 girls) were included in the study. The mean $( \pm$ SD) age of the boys and girls was $16.66 \pm 1.55$ and 22.61 \pm 4.09 years, respectively, and their mean BMI was $21.23 \pm 3.7$ and $22.61 \pm 4.09 \mathrm{~kg} / \mathrm{m} 2$, respectively. No statistical differences were found between the sexes in terms of age, BMI, or biochemical test results (Table 1). The majority of participants were eutrophic when analyzing the relationship between BMl and age. The mean values for all biochemical tests were within the recommendations for age and sex. Regarding body composition, it was observed that girls, as expected, exhibited a higher percentage of fat mass $(26.84 \pm 5,43 \%)$ than boys $(14.73 \pm 5,38 \%)(p<0.001)$ (Table 1).
There were no statistically significant differences between the sexes with regard to intake of carbohydrates, protein, and lipids. The mean macronutrient intake values were within normal limits for adolescents. However, energy consumption was $1223 \mathrm{kcal}$ higher in boys than in girls $(p=0.050)$ (Table 1$)$. When analyzing micronutrient intake, boys exhibited a higher intake of calcium ( $p=0.034)$, iron $(p=0.013)$, zinc $(p=0.026)$, vitamin $E(p=0.047)$, and sodium $(p=0.047)$ compared with girls. After adjusting for $\mathrm{BMl}$, differences between the sexes in calcium ( $p=0.044)$, iron ( $p=0.018)$, and zinc $(p=0.028)$ intake remained significant (Table 2). Considering nutrient intake inadequacies, in boys, the consumption of sodium was higher than the UL in $88.89 \%$, and folate and magnesium intake were inadequate in $50 \%$ and $33.33 \%$, respectively (Table 3). In girls, sodium intake was higher than the UL in $85 \%$, and intake of folate and calcium were inadequate $(65 \%$ and $55 \%$, respectively) (Table 4).

\section{Table 1}

Sample characteristics according to age, BMI, body composition, biochemical profile and macronutrient consumption

\begin{tabular}{|c|c|c|c|}
\hline SAMPLE CHARACTERISTICS & $\begin{array}{l}\text { GIRLS } \\
(\mathrm{N}=20)\end{array}$ & $\begin{array}{c}\text { BOYS } \\
(\mathrm{N}=18)\end{array}$ & $P$ \\
\hline Age $\left(\right.$ years) ${ }^{\mathrm{a}}$ & $16.39 \pm 1.62$ & $16.66 \pm 1.55$ & 0.609 \\
\hline BMI for Age Z-score ${ }^{b}$ & $-0.06 \pm 0.27$ & $0.66 \pm 0.29$ & 0.082 \\
\hline$\%$ fat mass ${ }^{b}$ & $26.84 \pm 5.43$ & $14.73 \pm 5.38$ & $<0.001^{*}$ \\
\hline $\mathrm{HDL}(\mathrm{mg} / \mathrm{dL})^{\mathrm{b}}$ & $44.85 \pm 9.64$ & $40.61 \pm 8.83$ & 0.166 \\
\hline $\mathrm{LDL}(\mathrm{mg} / \mathrm{dL})^{\mathrm{b}}$ & $89.83 \pm 18.25$ & $80.07 \pm 19.75$ & 0.124 \\
\hline Triglycerides $(\mathrm{mg} / \mathrm{dL})^{\mathrm{b}}$ & $73.35 \pm 32.03$ & $69.33 \pm 43.20$ & 0.745 \\
\hline Fasting Glucose $(\mathrm{mg} / \mathrm{dL})^{\mathrm{b}}$ & $82.00 \pm 6.29$ & $83.44 \pm 7.92$ & 0.536 \\
\hline Insulin $(\mathrm{uU} / \mathrm{mL})^{\mathrm{b}}$ & $14.17 \pm 6.83$ & $14.02 \pm 6.58$ & 0.948 \\
\hline Total cholesterol $(\mathrm{mg} / \mathrm{dL})^{\mathrm{b}}$ & $149.35 \pm 24.23$ & $134.55 \pm 22.38$ & 0.059 \\
\hline Energy $(\text { Kcal })^{\mathrm{C}}$ & $4272.61 \pm 2092.99$ & $3049.61 \pm 1570.80$ & 0.050 \\
\hline Protein (\% of total caloric intake) ${ }^{c}$ & $11.22 \pm 2.27$ & $12.09 \pm 2.87$ & 0.315 \\
\hline Carbohydrate (\% of total caloric intake) ${ }^{c}$ & $55.95 \pm 6.15$ & $54.56 \pm 5.92$ & 0.499 \\
\hline Fat (\% of total caloric intake) ${ }^{c}$ & $32.81 \pm 5.53$ & $33.36 \pm 4.39$ & 0.759 \\
\hline
\end{tabular}

${ }^{a}$ Chi-square test. Data expressed as absolute (n) and relative (\%) frequencies

b Student's t-test. Data expressed as mean \pm SEM (SEM=standard error mean)

${ }^{\circ}$ Student's $t$-test. Data expressed as mean \pm Std. deviation. One outlier were excluded from macronutrients analyzes.

${ }^{*} \mathrm{p}<0.05$

\section{Table 2}

Sample characterization according to micronutrients intake

\begin{tabular}{|c|c|c|c|c|c|c|}
\hline \multicolumn{7}{|c|}{$\begin{array}{l}\text { SAMPLE CHARACTERISTICS ACCORDING MICRONUTRIENTS INTAKE. } \\
\text { VALUES WITHOUT ADJUSTMENT }\end{array}$} \\
\hline $\begin{array}{l}{ }^{3} \text { ANCOVA } \\
\text { ADJUSTED BY BMI }\end{array}$ & & & & & & VALUES \\
\hline MICRONUTRIENTS & $\begin{array}{c}\text { BOYS } \\
(\mathrm{N}=18)\end{array}$ & $\begin{array}{l}\text { GIRLS } \\
(\mathrm{N}=20)\end{array}$ & $P$ & BoYs & GIRLS & $P$ \\
\hline${ }^{1}$ Calcium (mg) & $1661.53 \pm 203.25$ & $1142.47 \pm 111.17$ & $0.034^{\star}$ & $1633.77 \pm 163.49$ & $1166.06 \pm 150.54$ & $0.044^{*}$ \\
\hline${ }^{1}$ Iron (mg) & $30.46 \pm 3.93$ & $18.77 \pm 1.95$ & $0.013^{\star}$ & $29.93 \pm 3.09$ & $19.26 \pm 2.93$ & $0.018^{\star}$ \\
\hline${ }^{2}$ Zinc (mg) & $18.19[11.74 ; 24.59]$ & $12.32[8.63 ; 17.28]$ & $0.026^{\star}$ & $19.56 \pm 2.17$ & $12.64 \pm 2.06$ & $0.028^{\star}$ \\
\hline${ }^{2}$ Folate (mcg) & $331.90[251.44 ; 530.86]$ & 278.40 [199.88;369.97] & 0.121 & $516.90 \pm 106.54$ & $308.55 \pm 100.98$ & 0.168 \\
\hline${ }^{2}$ Magnesium (mg) & $512.35[310.37 ; 717.90]$ & $380.07[283.16 ; 479.23]$ & 0.114 & $604.68 \pm 97.13$ & $410.09 \pm 92.06$ & 0.158 \\
\hline${ }^{2}$ Vitamin A (mcg) & $1046.75[677.50 ; 1697.43]$ & 801.36 [531.81;1004.73] & 0.085 & $1514.80 \pm 264.91$ & $831.32 \pm 251.09$ & 0.072 \\
\hline${ }^{2}$ Vitamin E (mg) & $18.76[15.98 ; 36.04]$ & $14.37[11.18 ; 21.95]$ & $0.047^{\star}$ & $28.23 \pm 4.12$ & $16.89 \pm 3.90$ & 0.055 \\
\hline${ }^{2}$ Vitamin C (mg) & 324.11 [151.33;573.25] & $181.45[108.77 ; 336.54]$ & 0.114 & $517.89 \pm 140.72$ & $237.41 \pm 133.38$ & 0.160 \\
\hline${ }^{2}$ Sodium (g) & $4.82[3.42 ; 8.45]$ & $3.12[2.42 ; 4.69]$ & $0.047^{\star}$ & $5.67 \pm 0.69$ & $4.02 \pm 0.65$ & 0.094 \\
\hline
\end{tabular}

1 Student's t-test. Data expressed as mean \pm SEM (SEM = standard error mean)

${ }^{2}$ Mann-Whitney Test. Data expressed as median [q1:q2]

${ }^{3}$ Ancova Test. Adjusted values of micronutrients expressed as mean \pm SEM. Adjusted by $B M I=21.96$ ${ }^{*} \mathrm{p}<0.05$ 
Table 3

Inadequacy of micronutrients intake in boys

\begin{tabular}{|c|c|c|c|c|c|c|c|c|}
\hline \multirow[b]{2}{*}{ MICRONUTRIENTS } & \multirow[b]{2}{*}{ MEAN } & \multirow[b]{2}{*}{ SEM } & \multirow[b]{2}{*}{$\begin{array}{l}\text { STANDARD } \\
\text { DEVIATION }\end{array}$} & \multirow[b]{2}{*}{ MEDIAN } & \multicolumn{2}{|c|}{$\begin{array}{c}\text { 14-18AGE } \\
\text { BOYS }(\mathrm{N}=18)\end{array}$} & \multicolumn{2}{|c|}{$\begin{array}{l}\text { INADEQUACY } \\
\text { INTAKE } \\
\end{array}$} \\
\hline & & & & & MÍN-MAX & EAR & $\%$ & $\mathbf{N}$ \\
\hline Calcium (mg) & 2078.90 & 459.25 & 1948.44 & 1626.66 & $374.08-9174.07$ & 1100 & 27.78 & 5 \\
\hline Iron (mg) & 30.46 & 3.93 & 16.7 & 24.98 & $6.69-71.69$ & 7.7 & 5.56 & 1 \\
\hline Zinc (mg) & 19.85 & 2.88 & 12.24 & 18.18 & $4.57-56.95$ & 8.5 & 11.11 & 2 \\
\hline Vitamin $A(\mu \mathrm{g} / \mathrm{d})$ & 1545.66 & 371.08 & 1574.37 & 1046.74 & $310.52-6774.30$ & 630 & 22.22 & 4 \\
\hline Vitamin E (mg/d) & 28.66 & 5.55 & 23.58 & 18.76 & $4.38-101.44$ & 12 & 16.67 & 3 \\
\hline Vitamin C $(\mathrm{mg} / \mathrm{d})$ & 522.41 & 195.57 & 829.73 & 324.11 & $79.20-3727.37$ & 63 & 0.00 & 0 \\
\hline Folate $\mu \mathrm{g} / \mathrm{d}$ & 532.75 & 150.98 & 640.58 & 331.89 & $122.15-2952.19$ & 330 & 50.00 & 9 \\
\hline Magnesium & 614.72 & 131.64 & 558.51 & 512.35 & 106.91-2668.79 & 340 & 33.33 & 6 \\
\hline Sodium g/d & 5.74 & 0.80 & 3.40 & 4.82 & $1.28-13.50$ & $2.3^{*}$ & 88.89 & 16 \\
\hline
\end{tabular}

*UL.

SEM: Standard Error Mean

Table 4

Inadequacy of micronutrient intake in girls

\begin{tabular}{|c|c|c|c|c|c|c|c|c|}
\hline \multirow[b]{2}{*}{ MICRONUTRIENTS } & \multirow[b]{2}{*}{ MEAN } & \multirow[b]{2}{*}{ SEM } & \multirow[b]{2}{*}{$\begin{array}{l}\text { STANDARD } \\
\text { DEVIATION }\end{array}$} & \multirow[b]{2}{*}{ MEDIAN } & \multicolumn{2}{|c|}{$\begin{array}{c}\text { 14-18AGE } \\
\text { GIRLS }(N=20)\end{array}$} & \multicolumn{2}{|c|}{$\begin{array}{l}\text { INADEQUACY } \\
\text { INTAKE } \\
\end{array}$} \\
\hline & & & & & MÍN-MAX & EAR & $\%$ & N \\
\hline Calcium (mg) & 1142.4702 & 111.18 & 497.20 & 1063.101 & $422.13-2542.94$ & 1100 & 55 & 11 \\
\hline Iron (mg) & 18.77 & 1.95 & 8.72 & 16.21 & $7.06-41.40$ & 7.9 & 5 & 1 \\
\hline Zinc (mg) & 12.37 & 1.07 & 4.81 & 12.31 & $3.71-18.93$ & 7.3 & 10 & 2 \\
\hline Vitamin $\mathrm{A}(\mu \mathrm{g} / \mathrm{d})$ & 803.545 & 75.96 & 339.74 & 801.35 & $176.85-1512.94$ & 485 & 15 & 3 \\
\hline Vitamin E $(\mathrm{mg} / \mathrm{d})$ & 16.49 & 1.77 & 7.94 & 14.36 & $4.95-32.07$ & 12 & 30 & 6 \\
\hline Vitamin C $(\mathrm{mg} / \mathrm{d})$ & 233.33 & 38.51 & 172.23 & 181.45 & 28.81-746.92 & 56 & 10 & 2 \\
\hline Folate $(\mu \mathrm{g} / \mathrm{d})$ & 294.28 & 27.53 & 123.14 & 278.39 & $96.83-611.73$ & 330 & 65 & 13 \\
\hline Magnesium(mg/d) & 401.04 & 40.71 & 182.08 & 380.07 & $136.58-932.68$ & 300 & 30 & 6 \\
\hline Sodium g/d & 3.94 & 0.52 & 2.33 & 3.12 & $1.43-10.65$ & $2.3^{*}$ & 85 & 7 \\
\hline
\end{tabular}

*UL.

SEM: Standard Error Mean

\section{DISCUSSION OF RESULTS}

Results of this study revealed that boys and girls both exhibited inadequate intake of folate and excessive intake of sodium, whereas inadequate calcium intake was observed only in girls. We verified that $55 \%$ of the girls consumed less calcium than recommended. Similar to our study, Assumpção et al. found higher calcium inadequacy in girls than in boys (92.2\% versus $85.1 \%$, respectively) (13). Gomes et al. observed that $>90 \%$ of adolescents of both sexes had an intake of calcium and other nutrients considered inadequate for age. It is extremely important that adolescents consume sufficient amounts of calcium because growth and maintenance of peak bone mass occur predominantly at this stage of life $(14,15)$.

Studies suggest that inadequate calcium intake may occur due to omission of breakfast and/or other main meals (16). Fiuza et al. reported a breakfast omission rate of $32.5 \%$ in adolescents (predominantly girls), and this behavior was attributed to lifestyle and demographic factors (16).

In the present study, we observed inadequate folate intake in $65 \%$ of girls and $50 \%$ of boys. Another study involving adolescents in Brazil found a prevalence of $15.2 \%$ folate intake inadequacy. This was evaluated using a non-consecutive 3-day food registration instrument. We acknowledge that this is a lower prevalence compared to our study, but may be explained by better acess to dietary sources of folate and the consumption of fortified foods (17).

The results regarding excessive sodium consumption were concerning. The sodium intake higher than the Tolerable Upper Intake Level (UL) in
$88.89 \%$ of boys and $85 \%$ of girls were verified. Costa et al. evaluated 81 families and observed an average sodium intake of $7.66 \mathrm{~g} /$ day/ person, which corresponds to $3098.81 \mathrm{mg}$ of sodium/day/person. Prolonged excessive sodium consumption can increase the risk for hypertension, acute myocardial infarction, renal failure, and stroke (18). The study by Veiga et al. also found similar results, given that $>70 \%$ of the younger individuals exhibited excessive sodium consumption: $81 \%$ in boys, 10 to 13 years of age and $88.4 \%$ in those 14 to 18 years of age; $75.1 \%$ in girls 10 to 13 years of age and $69.9 \%$ in girls 14 to 18 years of age (19). An interesting study with adolescents using the method of $24 \mathrm{~h}$ urinary sodium excretion demonstrated that only $9.8 \%$ of boys and $22 \%$ of girls reached the World Health Organization (WHO) recommendations for sodium intake. Further, it demonstrated a diet rich in sodium intake in the adolescents (20). In the present study, we did not use the gold standard method to measure the sodium intake (24h urinary sodium excretion). This is a limitation of our study.

It is important to highlight that the quality of the food consumed was not evaluated in the present study. High consumption of ultra-processed foods during adolescence is currently observed. A study by D'Avila found that $50 \%$ of adolescents exhibited high consumption of ultra-processed foods in their diet, corresponding to $1496.5 \mathrm{Kcal} /$ day in total energy intake. Evidence indicates that this type of food is excessively consumed in high-income countries. In Brazil, as well as in other middle-income countries, it has been verified that the intake of ultra-processed foods has been increasing rapidly, which is directly related to high sodium consumption (21). 
Results regarding macronutrient consumption revealed that carbohydrate, protein, and lipid intake were within the limits recommended by DRIs. These results corroborate those of a few studies that evaluated sex-specific macronutrient intake in adolescents. Souza et al. identified an average carbohydrate consumption of $54 \%$ and $53 \%$, protein consumption of $15 \%$ and $16 \%$, and lipid consumption of $31 \%$ and $30 \%$ in girls and boys, respectively (22). In addition, Vieira et al. reported that the dietary intake of eutrophic overweight adolescents was within the limits recommended by DRIs (23).

Another point that needs to be discussed is the use of the semiquantitative FFQ as an instrument for assessing food consumption. Most studies use food recall to assess food inadequacy $(13,22)$. It is believed that the FFQ may be an additional instrument that can be used to assess food consumption. This instrument reflects habitual food consumption and can be applied at once; however, it can be affected by memory bias because it requires the cooperation of those interviewed in retrospectively recalling their consumption. It is worth highlighting that the FFQ is an instrument frequently used in epidemiological studies to qualitatively evaluate food consumption. Our research used a validated instrument to access the information of consumption (FFQ). It is a strong point of the study. In addition, we performed the analyses by sex.

\section{CONCLUSIONS}

The FFQ is an interesting tool for evaluating food consumption. Adolescents of both sexes had a high prevalence of inadequate folate and excessive sodium intake, and calcium consumption was inadequate, specifically in girls. We can infer that if micronutrient consumption remains inadequate in this important stage of development, these adolescents may develop health problems related to a deficiency in these micronutrients throughout their lives, especially chronic noncommunicable diseases. In addition, it should be noted that these nutritional deficits could have an important impact on gestation, affecting mother-baby binomial health.

\section{ACKNOWLEDGMENTS}

Financial support was received from the Brazilian National Council for Technological and Scientific Development, Fundo de Incentivo à Pesquisa e Eventos do Hospital de Clínicas de Porto Alegre (FIPE/HCPA).

\section{REFERENCES}

1. Monteiro LS, Rogerio Melo Rodrigues PRM, Veiga GV, Marchioni DML, Pereira RA . Diet quality among adolescents has deteriorated: a panel study in Niterói, Rio de Janeiro State, Brazil, 2003-2008. Cad Saúde Pública. 2016;32(12) e00124715.

2. Enes CC, Slater B. Obesity in adolescence and its main determinants. Rev bras epidemiol. 2010;13(1):163-71.

3. Selem SS, Carvalho AM, Verly-Junior E, Carlos JV, Teixeira JA, Marchioni DM, et al. Validity and reproducibility of a food frequency questionnaire for adults of Sao Paulo, Brazil. Rev Bras Epidemiol. 2014;17(4):852-9.

4. Trumbo PR, Barr SI, Murphy SP, Yates AA. Dietary reference intakes: cases of appropriate and inappropriate uses. Nutr Rev. 2013;71(10):657-64.

5. Leao AL, dos Santos LC. [Micronutrient consumption and overweight: is there a relationship?]. Rev Bras Epidemiol. 2012;15(1):85-95.

6. Veiga GV, Costa RS, Araujo MC, Souza Ade M, Bezerra IN, Barbosa Fdos S, et al. Inadequate nutrient intake in Brazilian adolescents. Rev Saude Publica. 2013;47 Suppl $1: 212 \mathrm{~s}-21 \mathrm{~s}$.

7. Henn RL, Fuchs SC, Moreira LB, Fuchs FD. Development and validation of a food frequency questionnaire (FFQ-Porto Alegre) for adolescent, adult and elderly populations from Southern Brazil. Cad Saude Publica. 2010;26(11):2068-79.
8. Pinheiro ABV, Lacerda EMdA, Benzecry E, Haim, Gomes MCdS, Costa VM. Tabela para avaliação de consumo alimentar em medidas caseiras. Rio de Janeiro: Atheneu; 2005. 9. Institute of Medicine Standing Committee on the Scientific Evaluation of Dietary Reference I. The National Academies Collection: Reports funded by National Institutes of Health. Dietary Reference Intakes for Calcium, Phosphorus, Magnesium, Vitamin D, and Fluoride. Washington (DC): National Academies Press (US)National Academy of Sciences.; 1997.

10. Institute of Medicine Panel on M. Dietary Reference Intakes for Vitamin A, Vitamin K, Arsenic, Boron, Chromium, Copper, lodine, Iron, Manganese, Molybdenum, Nickel, Silicon, Vanadium, and Zinc. Washington (DC): National Academies Press (US)Copyright 2001 by the National Academy of Sciences. All rights reserved.; 2001.

11. Trumbo P, Schlicker S, Yates AA, Poos M. Dietary reference intakes for energy, carbohydrate, fiber, fat, fatty acids, cholesterol, protein and amino acids. J Am Diet Assoc. 2002;102(11):1621-30.

12. World Health Organization. WHO child growth standards: length/height-for-age, weight-for-length, weight-for-height: and body mass index-for-age. Methods and development. WHO (nonserial publication). Geneva, Switzerland: WHO; 2006.

13. de Assumpcao D, Dias MR, de Azevedo Barros MB, Fisberg RM, de Azevedo Barros Filho A. Calcium intake by adolescents: a population-based health survey. J Pediatr (Rio J). 2016;92(3):251-9.

14. Bueno AL, Czepielewski MA. The importance for growth of dietary intake of calcium and vitamin D. J Pediatr (Rio J). 2008;84(5):386-94.

15. Golden NH, Abrams SA. Optimizing bone health in children and adolescents. Pediatrics. 2014;134(4):e1229-43.

16. Fiuza RFDP, Muraro AP, Rodrigues PRM, Sena EMS, Ferreira MG. Skipping breakfast and associated factors among Brazilian adolescents. Rev Nutr. 2017;30(5):615-26. 17. Steluti J, Martini LA, Peters BS, Marchioni DM. Folate, vitamin B6 and vitamin B12 in adolescence: serum concentrations, prevalence of inadequate intakes and sources in food. J Pediatr (Rio J). 2011;87(1):43-9.

18. Costa FP, Machado SH. Does the consumption of salt and food rich in sodium influence in the blood pressure of the infants? Ciênc saúde coletiva. 2010;15:1383-9. 19 Veiga GV, Costa RS, Araujo MC, Souza Ade M, Bezerra IN, Barbosa Fdos S, et al. Inadequate nutrient intake in Brazilian adolescents. Rev Saude Publica. 2013;47 Suppl 1:212s-21s.

20. Gonçalves C, Abreu S, Padrão P, Pinho O, Graça P, Breda J, et.al. Sodium and potassium urinary excretion and dietary intake: a cross-sectional analysis in adolescents. Food \& nutrition research. 2016; 60:29442.

21. D'Avila HF, Kirsten VR. Energy intake from ultra-processed foods among adolescents. Rev Paul Pediatr. 2017;35(1):54-60.

22.Souza Ade M, Barufaldi LA, Abreu Gde A, Giannini DT, de Oliveira CL, dos Santos MM, et al. ERICA: intake of macro and micronutrients of Brazilian adolescents. Rev Saude Publica. 2016;50 Suppl 1:5s.

23. Vieira MV, Paulo UdS, Del Ciampo IRL, Paulo UdS, Del Ciampo LA, Paulo UdS. Food consumption among healthy and overweight adolescents. Journal of Human Growth and Development. 2014:24:157-62. 